\title{
Teaching and learning nursing management in the hospital context: an approach in the light of Pichon-Rivière*
}

\author{
Ensinar e aprender administração em enfermagem no contexto \\ hospitalar: um enfoque à luz de Pichon-Rivière \\ Enseñar y aprender administración de enfermería en el marco \\ hospitalario: un enfoque a la luz de Pichon-Rivière
}

\section{Dagmar Elaine Kaiser ${ }^{1}$, Clarice Maria Dall'Agnol ${ }^{1}$}

\section{How to cite this article:}

Kaiser DE, Dall'Agnol CM. Teaching and learning nursing management in the hospital context: an approach in the light of Pichon-Rivière. Rev Esc Enferm USP. 2017;51:e03261. DOI: http://dx.doi.org/10.1590/S1980-220X2017018803261

* Extracted from the thesis "Do implícito ao explícito: o ensinar/aprender administração em enfermagem no contexto hospitalar”, Programa de Pós-Gradução em Enfermagem, Universidade Federal do Rio Grande do Sul, 2015.

${ }^{1}$ Universidade Federal do Rio Grande do Sul, Escola de Enfermagem, Porto Alegre, RS, Brazil.

\begin{abstract}
Objective: Analyze the articulation of students, professors (supervisors of the undergraduate practicum) and nursing professionals in teaching and learning nursing management at graduation in a public university hospital. Method: This is a study of qualitative approach, anchored in the operative group reference of Pichon-Rivière. Data collection was held between October 2013 and September 2014 and consisted of a selfadministered questionnaire, participant observation and focus group. The information was submitted to thematic analysis. Results: The thematic analysis of the corpus resulted in four themes: the unknown and the inevitable; in coming and going, attitudes, values and new bonding; the dialogue and ways of acting in the teaching/learning; the emergence of praxis. Conclusion: The articulation among students, supervisors and nursing professionals occurring in a coming and going of attitudes, values and new bonding, in which the dialogue enables ways of acting in the teaching/learning of nursing management in graduation, allowing the emergence of praxis.
\end{abstract}

\section{DESCRIPTORS}

Nursing Administration Research; Education, Nursing; Students, Nursing; Focus Groups. 


\section{INTRODUCTION}

The present study situates the teaching and learning of nursing management at undergraduate level as a continuous and dialectical learning experience in which students, professors (supervisors of the undergraduate practicum) and nursing professionals interact in the practice setting in coordination with an own time in a process of creation and discoveries ${ }^{(1)}$. Thus, the study supports the convergent epistemology $y^{(2)}$ by referring to an integrated view of man in situation.

The reason for conducting the study comes from the teaching experience in the area of nursing management driven towards the understanding of the here and now with the personal history of those involved in education at a public teaching hospital. By empirical observation in the teaching path, students, supervisors and nursing professionals experience countless situations in which they relate to each other by expressing desires and emotions particular of the academic and hospital world, and experiencing ambivalent feelings at times. When students find themselves academically assuming the managerial role of nurses, they are faced with confrontations that can trigger often conflicting and antagonistic impressions in the inpatient unit of their undergraduate practicum, and these reflect on their learning( ${ }^{(3)}$, as well as in patient care and the organizational culture as a whole ${ }^{(4)}$.

When supervisors are concerned about improving pedagogical approaches and students' integration in the nursing team, and plan a group process that enhances students, supervisors and nursing professionals in the relation with others, they face the complex reality involving student learning and qualification of teams for change and transformation.

On the other hand, when nursing professionals experience the interactive dimension of group processes that integrate teaching and learning in the production of care, they wonder about their preparation for a learning-oriented action. These dimensions comprise a group of reasons, needs and aspirations subordinated to the task ${ }^{(2,5)}$ and report to the interaction in the learning process.

The theories of Enrique Pichon-Rivière supported the understanding of interactions in this group insertion ${ }^{(2)}$. He was an Argentinian psychiatrist of Swiss origin, and made remarks about the group relationships in order to reach support and understanding of internalized social agendas that organize the concrete forms of interaction. In other words, the social relations and those of subjects inserted in these relationships ${ }^{(6)}$ in a dialectical proposal. The task ${ }^{(5)}$ is the structuring concept of the group process. It occurs as a group and goes beyond the idea of a job or activity to be performed as common sense representations could lead to understand ${ }^{(5)}$, but means something dynamic and moving, when the quality of teaching and learning nursing management may affect health care and professional development. In this perspective, the group action supports its members, i.e., the task mobilizes the group and the dynamics that permeate and articulate its path in the explicit and implicit dimensions. This implies a critical action and reflection about the educational process $^{(7)}$ and the relationships established for the sake of learning ${ }^{(8)}$. What is propagated and exposed is firstly what is formally put in the teaching of nursing management, such as the objectives of the programed teaching activities. What comes next and must be conjectured is implicit and gives clues in the form of resistance and difficulties, i.e., the pre-tasks will be revealed with the group movement and provide support for interventions and reorientation of the teaching and learning of nursing management, requiring a little more attention and ability to make analogies and conclusions.

In this perspective, the referential of Pichon-Rivière provides an important theoretical framework that supports the understanding and analysis for the gradual integration of students in the hospital undergraduate practicum. In addition, it helps to identify the present concerns for developing the undergraduate practicum activities, and explore ideas and experiences related to group interaction for managing the production of nursing care in line with the strategies adopted by those involved regarding the advances and limitations of learning ${ }^{(1)}$. From there, are seen paths for promoting adequate conditions for teaching and learning nursing management in patient care ${ }^{(9-10)}$ that qualify the nursing staff performance in this period.

Considering the given context, the objective of this study ${ }^{(1)}$ was to analyze the articulation of students, supervisors and nursing professionals among themselves in teaching and learning nursing management at undergraduate level in a public university hospital. The look was expanded in a way that in this formative, scientific, historical and social context, the involved actors can develop alternatives in group to overcome the contradictions faced with the obstacles present in the healthcare space.

\section{METHOD}

This is a study of qualitative approach ${ }^{(11)}$ supported in Pichon-Rivière's framework ${ }^{(2)}$ of operative group, in which was exercised a dialectical relationship between the real world and the subject. The study field took place in a public, quaternary, general and teaching hospital. The focus of the study were the interpersonal relations between students and supervisors in theoretical and practical activities of nursing management, and nursing professionals working in clinical and surgical units that host undergraduate practicum programs in the hospital. In addition, in the study were problematized situations of teaching and learning in nursing management produced and taken from the explicit knowledge that guides these performances.

Chart 1 provides an overview of the composition of study participants, taking into account the three data collection procedures.

The participant observation ${ }^{(11)}$ was conducted by the researcher following the undergraduate practicum program of two groups of students from Monday to Thursday, from 7 to $13: 15$ (total of 125 hours), distributed evenly in both units. Records were made in a journal and in many times they clarified situations and provided visibility about the group movement, which involved listening, hearing, seeing and making use of all senses to perpetrate the new. 
Chart 1 - Data collection procedures and study participants - Porto Alegre, RS, Brazil, 2015.

\begin{tabular}{|c|c|c|c|c|}
\hline \begin{tabular}{|ll} 
Data collection & Field/Participants \\
\end{tabular} & Period & Inpatient Units (IU) & Participants & $\mathrm{Nr}$ \\
\hline Participant observation & $\begin{array}{l}10 / 28 / 2013 \text { to } \\
11 / 28 / 2013\end{array}$ & $\begin{array}{l}1 \text { Surgical IU } \\
1 \text { Clinic IU }\end{array}$ & $\begin{array}{c}\text { - Supervisors (2) } \\
\text { - Students (10) } \\
\text { - Nursing prof. (5E, 15T/AE) }\end{array}$ & 32 \\
\hline Self-administered questionnaire & $10 / 2013$ to $11 / 2013$ & $\begin{array}{l}2 \text { Surgical IU } \\
2 \text { Clinic IU }\end{array}$ & $\begin{array}{c}\text { - Supervisors (8) } \\
\text { - Students (27) } \\
\text { - Nursing prof. (7E, 15T/AE) }\end{array}$ & 57 \\
\hline Focus group & 08/14/2014 & 1 Clinic IU & $\begin{array}{c}\text { - Supervisors (3) } \\
\text { - Students (1) } \\
\text { - Nursing prof. (2E, 1T/AE) }\end{array}$ & $7^{*}$ \\
\hline Focus group & 09/03/2014 & 1 Clinic IU & $\begin{array}{l}\text { - Supervisors (2) } \\
\text { - Students (1) } \\
\text { - Nursing prof. (2E, 1T/AE) }\end{array}$ & $5^{*}$ \\
\hline
\end{tabular}

* Criteria for selection of participants: interest in discussing the issue.

The self-administered questionnaire ${ }^{(11)}$ was built based on previous experience of the researcher and Pichon-Rivière's framework, consisting of five open questions, namely: What are your concerns about the beginning and development of the nursing management undergraduate practicum; When/ at what times these concerns are overcome; Describe some situations that (de)motivate group interaction in the inpatient unit/undergraduate practicum field; Do you reckon there is (is no) constructive dialogue opportunity in the team that involves supervisor, student, nurse and nursing technician/assistant? Comment on this; Would you like to speak about things that were not mentioned and interfere with the progress of the undergraduate practicum program? Explain. The questionnaire was submitted to validation by two $\mathrm{PhD}$ student nurses who had already assumed the undergraduate practicum on teaching activities of hospital nursing management. The instruments were available for completion in the units of undergraduate practicum, and study participants were given ten days to fill them out and return in collection boxes placed in the units.

The focus group ${ }^{(11-12)}$ occurred in two meetings that lasted two hours each, were recorded and transcribed in full. In the first meeting, were addressed two generating themes. First, were discussed the fears and anxieties of students, supervisors and nursing professionals in the insertion in the undergraduate practicum field. In a second time, was discussed the perception of the interaction between all in the search for group organization in the development of care management. At the second meeting, was addressed the extent to which students, supervisors and nursing professionals (co-participants in the training process for managing the production of care) have used the opportunities in the midst of academic activities to exchange managerial experiences and knowledge in order to strengthen commitment to learning and with the group. At each meeting, there was a warm-up period of the group, essential for exchange of ideas and group dynamics, as well as a period of synthesis and closure of discussions. Meetings were held in a previously scheduled room to provide comfort and privacy for the group and facilitate participation in the study. This also allowed the placement of participants in a way that all could see one another, the researcher and the non-participat observer, thereby promoting participation and group interaction. The researcher conducted discussions with help of the non-participant observer in logistic aspects such as monitoring the recording equipment, preparation of the physical environment, time control, recording of non-verbal forms of communication between participants and of participants' code at the beginning of their speech to facilitate understanding of dialogues.

The ethical aspects of the study were respected, following resolution $466 / 12^{(13)}$ that presents the regulatory guidelines and standards for research involving human subjects. The study was approved by the Ethics Committee on Institutional Research and is registered as Project Number 13.0399, CAAE 20568813.7.0000.5327.

The data were submitted to thematic content analysis ${ }^{(11)}$ in a process of critical analysis that considered the conflicting and antagonistic content of the studied reality in the search for connections between the empirical experience and the plan of group relations. The analytical method comprised three stages. First, information was organized in a pre-analysis that consisted of audio transcription and (re) reading of material of questionnaires, records of participant observation, and meetings of the focus group. Subsequently, information was classified in a process based on the theoretical assumptions of Pichon-Rivière from the information obtained. This classification process consisted of two distinct phases, namely the exhaustive and repeated reading of texts, by interrogating their information, and establishing a corpus. By deepening the analysis process, it was possible to remake and refine the classification movement, elaborating thematic categories and subcategories. The phase of final analysis was the inflection between empirical and theoretical data in a real dialectical movement, when the look and sensibility anchored in Pichon-Rivière's framework make a theory and empirical comparison movement.

\section{RESULTS}

For the presentation of the results, were adopted specific encodings referring to the different procedures of information collection. Therefore, with respect to:

a) Self-administered questionnaires: Q-A1, Q-A2 [...] correspond to students; Q-P1, Q-P2 [...] correspond to supervisors; Q-E1, Q-E2 [...] to nurses; and Q-T/ AE1, Q-T/AE2 [...] correspond to nursing technicians and assistants. 
b) Focus group: the coding GF-M corresponds to moderator; GF-A1, GF-A2 [...] to students; GF-P1, GF-P2 [...] to supervisors; GF-E1, GF-E2 [...] to nurses; GF-T/AE1, GF-T/AE2 [...] to nursing technicians or assistants. c) Participant observation: OP was adopted for the records of notes with general references to groups of students, supervisors and nursing professionals.

Chart 2 summarizes the organization of results given by the research participants.

Chart 2 - Thematic categories and subcategories - Porto Alegre, Rio Grande do Sul, Brazil, 2015.

\begin{tabular}{|c|c|}
\hline THEMATIC CATEGORIES & SUBCATEGORIES \\
\hline The unknown and the inevitable & $\begin{array}{l}\text { - In face of (in)security of the new } \\
\text { - Needs and motivations that drive or paralize } \\
\text { In the group setting, the deals and arrangements }\end{array}$ \\
\hline $\begin{array}{c}\text { In coming and going, attitudes, values and new } \\
\text { bondings }\end{array}$ & $\begin{array}{l}\text { - Group bonding processes in affiliation and belonging } \\
\text { - Ideologies of relevance } \\
\text { - Cooperation versus sabotage } \\
\text { - Communication facilities, the noises and misunderstandings } \\
\text { - Dimensions of learning and the obstacles } \\
\text { Positive and negative tele }\end{array}$ \\
\hline $\begin{array}{c}\text { The dialogue and ways of acting in the teaching/ } \\
\text { learning }\end{array}$ & $\begin{array}{ll}\text { - } & \text { Signalizations and remarks } \\
& \text { Contradictions and conflicts in the face of obstacles }\end{array}$ \\
\hline The emergence of praxis & - Perspectives of teaching/learning nursing management in the hospital context \\
\hline
\end{tabular}

The results shown in chart 2 are detailed below.

The unknown and the inevitable - In the teaching and learning activities of nursing management in the hospital, students, supervisors and nursing professionals face new experiences and impressions when they see and are seen, hear and are heard in the group, introducing the novelty and originality they bring with themselves. Thus, the confrontation of the unknown and inevitable, which is nothing more than the explosion of an asleep feeling at the beginning of these activities, tends to allow everyone to show and prove who they are. This interaction prints a web of relationships formed by acts and communication by starting a process of revealing impressions and identities in the presence of others, and sometimes faced with impressions and identities of contemporary ones, and that arise from previous experiences.

In face of the (in)security of the new, there are intense anxieties in the beginning of the nursing management undergraduate practicum. Figure 1 summarizes such anxieties.

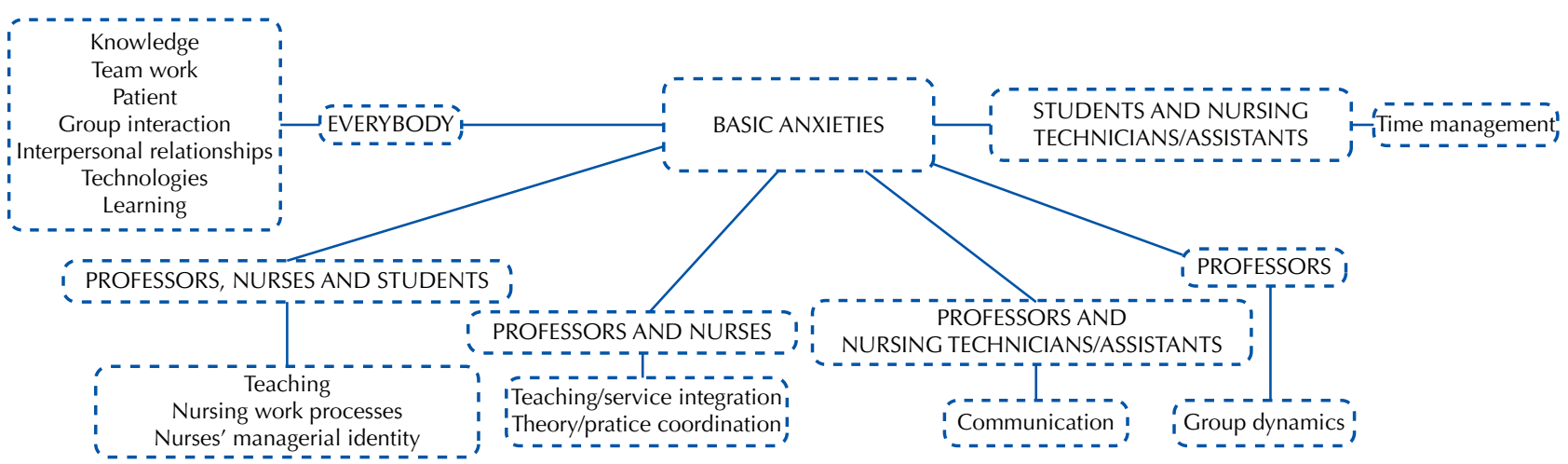

Figure 1 - Basic anxieties mobilizing students, supervisors and nursing professionals at the beginning of nursing management teaching activities in hospitals - Porto Alegre, Rio Grande do Sul, Brazil, 2015.

Students, supervisors and nursing professionals referred to management in production of nursing care as a participatory process, having the other as a contribution to their needs so that together they can experience the professional and academic development:

During the undergraduate practicum development, I care about creating different experiences to students, showing them the 'action' of the nurse. They arrive with difficulties and I care about tracing this bridge (Q-E6).

On the other hand, the motivations that drive or paralyze the teaching/learning were recalled from experiences:

(...) the management undergraduate practicum has a peculiar feature in our curriculum because it represents the student's opportunity to be included and work with the nursing staff, taking over the managerial duties of nurses, in addition to the care functions emphasized so far. The interaction between students and professionals, nursing and others is a condition for the development of the undergraduate practicum. For the team, it is very important to notice and create an atmosphere of trust, partnership and cooperation, emphasizing the role they develop in the training of nurses (Q-P5).

We, technicians, consider this undergraduate practicum program as a very intense exchange of experiences with students. During coexistence, the bonds are strengthened, gaining respect, trust, and knowledge exchange (Q-T/AE13).

The commitments made by students, supervisors, nurses and nursing technicians/assistants in the critical (re)reading of reality are often seen as barriers to interaction by 
not establishing a civility relationship in convivial. Thus, regarding the group setting, the deals and arrangements were deemed necessary for teamwork, since these aspects comprise the undergraduate practicum rules, but not always the group movement:

(...) in every new undergraduate practicum group, the initial deals and commitments made bilaterally are crucial for the interns' integration in the team (Q-P6).

In coming and going, attitudes, values and new bonding - Some phenomena of human interaction appear with some regularity in the group movement based on the dual character of how opposing forces influence the teaching/learning. Group bonding processes in affiliation and belonging were identified in clinical practice, in the academic/professional field:

Being accepted is a need in all new groups where I insert myself, but in this group, I think there is an extra need to prove I can. It is not only joining the team, but to do and be able to help the team to work. And manage all that (GF-A1).

In general, gestures, speeches and the commitment itself assumed by those involved with the undergraduate practicum allowed the identification of relevant ideologies related to the nursing management content and the learning results of students:

Nursing professionals arrive at the unit early, before $7 A M$, and organize themselves for patient care by developing consensus regarding the goals to be achieved in the work shift taking into consideration the technical skills, and together with students and the supervisor (OP).

On the other hand, it is noteworthy that some limitations experienced throughout the nursing management undergraduate practicum required more consistent investments for changing such conditions. A nurse revealed latent contents of maximum relevance and direct involvement in managerial work with regard to cooperation versus sabotage: (...) when I advise students, I am investing in order that from that point onwards they can do on their own. Maybe I lose time today, but I will win tomorrow, because these students will be able to stand on their own feet (GF-E1).

In this demand, the communication facilities, noises and misunderstandings are related to personal insecurity or being misunderstood, or even the fear of suffering with negative reactions or of discredit in the team. An example of these situations:

It is important that students know the work process of nursing technicians so they realize that there will be times when they won't be able to serve students, and this can be justified by the work demands, and not because they simply don't want to answer the students' request (Q-P2).

Thus, dimensions of learning and obstacles that enable students to understand the universe in which they are inserted and qualify this space are lacked:

The various activities happening in the undergraduate practicum made me the student I am today. The team has great participation in it, for having trusted me and allowed me to assume with them situations that required the presence of nurses (Q-A12).
People's positive or negative ability or disposition to articulate themselves in the undergraduate practicum program also are lacked. In other words, the positive and negative tele determines subjectivities impregnated of collective content that need to become increasingly aware and criticized in order that people do not alienate themselves nor converge to the alienation of others:

The undergraduate practicum gives us the opportunity to work with good students, engaged and committed from the beginning until the end of the undergraduate practicum program. These are the professionals we would like to have by our side at the units (Q-E2).

The dialogue and ways of acting in the teaching/learning - From the results emerged signs and observations with involvement of the group of students, supervisors and nursing professionals regarding the peculiarity of the group work. These manifestations included conflicts, anxieties, and the unsaid, among other expressions and indications that hide desires, power games, specifics of management practice, difficulties, tensions, understandings and challenges of people, including resistance possibilities and spaces of transformation. Through signs and observations, the students revealed how they build and exercise their roles from the teamwork, where they contribute with impressions, feelings and possibilities of improvement:

The nurses' list of work activities included the distribution of the unit's patients per nurse. There was also the list of activities of nursing technicians. So we quickly organized our own list of activities, of the students, to clarify the activities we would undertake (Q-A6).

Furthermore, their references to search for solutions in relation to dissatisfaction with interpersonal relationships, and the freedom and confidence to face the undergraduate practicum without fear, and despite the obstacles are necessary for the group's achievement of learning, although full of contradictions and conflicts in the confrontation of obstacles:

The interaction of students with the team often appears as an obstacle to learning. They often mention feeling little welcomed by the team in the midst of their doubts with the activities in the undergraduate practicum field (Q-P5).

The emergence of praxis - The explicit and implicit contents expand possibilities of teaching/learning nursing management in the hospital, when the trajectory of the group task in face of joint action shows that individual, social, cultural and political dimensions reiterate a praxis in which the partnership between students, supervisors and nursing professionals proves to be essential for an articulation particularly favorable for the teaching and learning of management (Figure 2).

On the other hand, the richness of hospital nursing work, and the importance of its contributions to identify the needs for training and the development of managerial skills by students were seen as essential ingredients for learning and the transformation of reality (Q-E1). 


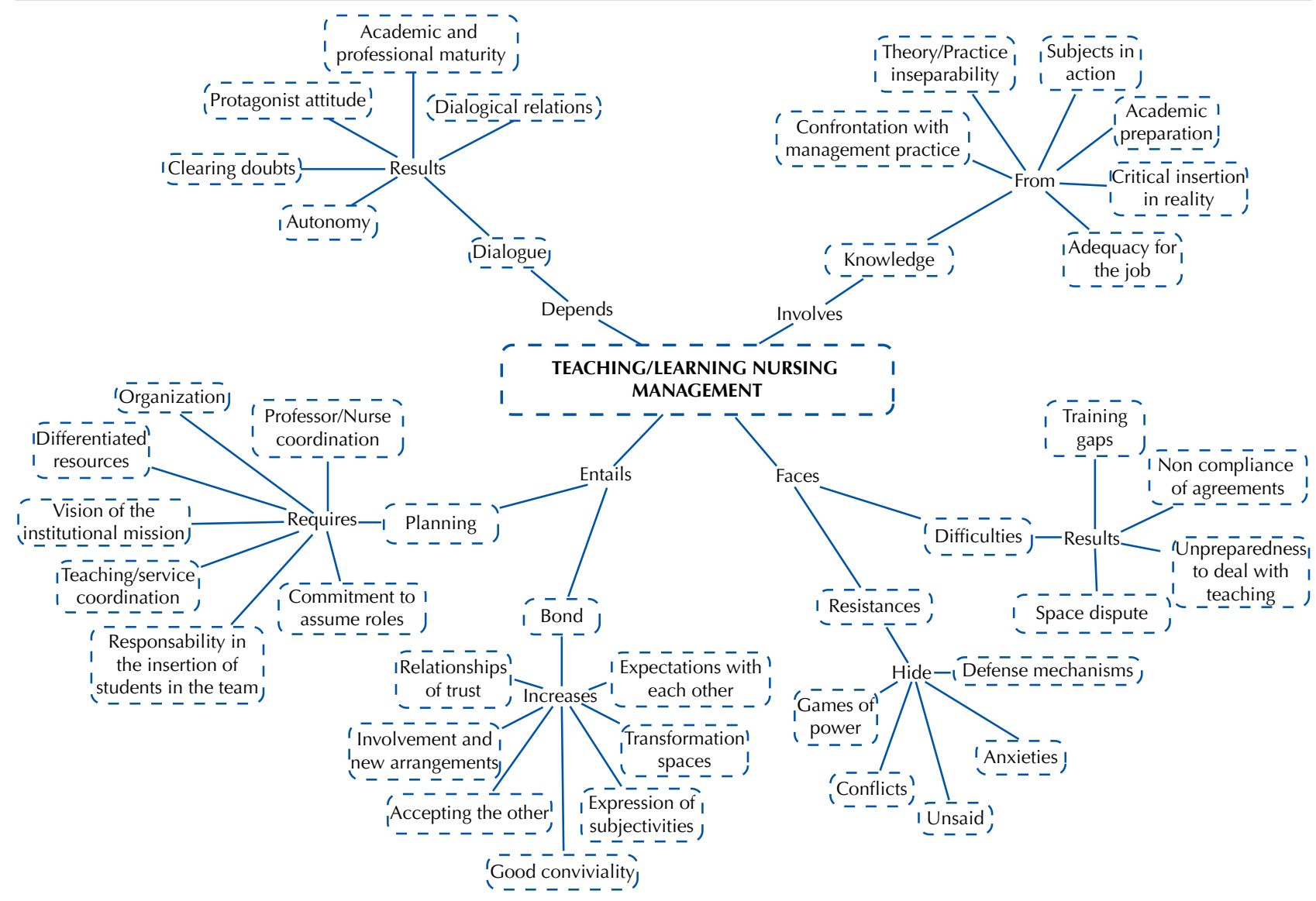

Figure 2 - Situational moments that move the group articulation in teaching and learning nursing management in hospitals - Porto Alegre, Rio Grande do Sul, Brazil, 2015.

\section{DISCUSSION}

In the beginning of the undergraduate practicum, there is intense mobilization of basic anxieties. In this demand are the plurality and conflict of the educational process, the nursing management practice in line with the profession and its ethical principles in collective spaces, with appreciation of subjectivities and in the perspective of articulation between the spheres of management and care in an active, critical and purposeful manner. The revelation of these anxieties is not sudden, but happens gradually by rescueing memories that unveil behaviors of those involved when faced with reality. A defensive position is assumed in an educational space of collective manifestation, and not only of its otherness, which can hinder, or even paralyze the demands of the undergraduate practicum program. In this context, students, supervisors and nursing professionals are related through voluntary actions or those unconsciously exercised and/or accepted by each person or by the group when faced with the unknown and inevitable. Thus, the explicit task is the common goal for which the group is organized. The implicit task involves the preparation of the basic anxieties to overcome the obstacles of the task itself $^{(5,14)}$ in the (in)security before the new. Then, there is an important concern with teaching, learning and the service with the unconscious aspects of the group performance.

When a group of people motivated by similar needs is united around a specific activity, interpersonal relationships conquer space in the search for information and new knowledge ${ }^{(2)}$. With focus on students' upgrade in the sense of advancing in learning, the people involved promote new webs of connections through collaborative attitudes in relation to the identity problematic sought by students of the nursing management undergraduate practicum, which evokes skills to be learned in group. However, the scope refers to the interplay amid contradictory pairs: need and satisfaction $^{(2)}$. The academic insertion in the nursing team is the experience of the work dimension of these professionals that similarly need to seek the knowledge and skills necessary for a competent, committed and responsible professional ${ }^{(1,15)}$ in order to contemplate the needs of student's learning and of the practice field ${ }^{(7,16)}$. There are needs and motivations that drive or paralyze and conjecture the group movement from components that are not explicit. Breaking these stereotypical structures that hinder interaction is very important to promote transformations that manifest the teaching/learning.

In the group setting, the deals and arrangements are made as guidelines, rules and norms. Then, it is crucial how students, supervisors and nursing professionals propose, sanction and confirm the group setting or deny and reject it, and oppose to the possibility of a common understanding regarding the undergraduate practicum. It is a key point that the group setting is given, not for the absence of conflicts but for the possibility to make them explicit in order that those involved can understand, explain, manage and address such conflicts in group ${ }^{(17)}$. In these shared relations, the otherness 
is revealed in the aspect of reciprocity that unites needs and evokes conditions to constitute a group.

Those involved seek and establish among themselves a set of meaningful exchanges of ideas, feelings, expectations and actions that are listed ${ }^{(18)}$ in the coming and going of attitudes, values and new bonds, received and responded in a course that gains history with transformation of the feeling of affiliation into belonging.

In order that the interpersonal coordination in teaching/ learning nursing management becomes a support network, each person must deal with their limitations and know how to deal with individual differences that may affect the group $^{(17)}$ to overcome conflicts resulting from the group processes of bonding in the affiliation and belonging of the group and practice field. While the belonging develops from the individual and conscious adherence of each person with the task, the affiliation involves the consent of belonging to the group ${ }^{(2)}$. This nuance accumulated in each individual in relation to assuming responsibilities in a group or alone is filled with the collective heritage of every person, hence peculiar and unique ${ }^{(19)}$.

Knowing what to do in every situation presupposes a judgment on any presented case $^{(2)}$ with mobilization of knowledge that promotes contact with the practice in its predictability and unpredictability due to ideologies of relevance.

In the educational process, in order that subject and the group disorganize themselves before the new knowledge, and re-organize themselves based on challenges that transform them, a movement between the inner and outer world ratifies and rectifies the Conceptual Referential Operative Schema - $\operatorname{CROS}^{(2,17)}$ continuously. CROS is a conceptual model shaped by schemes internalized by the subject throughout life. It is in constant movement from the interaction and confrontation with the context, that is, present in the apprehension of reality. When the subjects accept the concepts from daily life that result from the interplay of roles, they expand and modify their previous schemes and confront their internal models, setting a new CROS. The produced concepts will be the starting point for understanding the reality and the subjects will resort to them to act in each time they approach a new knowledge object they are trying to know, whose operability entails producing an action that modifies some aspect of reality. Thus, CROS is a product of social and individual history of students, supervisors, nurses and nursing technicians/assistants. Each of these subjects relates with their individual CROS and will confront their previous models and schemes formed throughout life, and from the relationship with the environment, they try to understand what happens to them, modifying themselves as they transform themselves, forming the group CROS.

When relating to their individual CROS, students, supervisors and nursing professionals, try to understand what happens to them, forming the group $\mathrm{CROS}^{(2)}$. This mobilization drives the group so that everyone can do their best, converging to ensure the availability shared by all ${ }^{(14)}$, and relevant in a scenario of cooperation versus sabotage. When subjects know who is with them and how they internalize the other, they articulate themselves. From this point of view, each group is unique, peculiar and unrepeatable.

When people are unable to deal with a practical situation, or when certain concerns do not have resonance and cooperation in the group, the interpersonal relationships will be more difficult. Therefore, communication facilities, noise and misunderstandings may prevent the action of others and lead to a position of resistance and sabotage of the teaching/learning and production of nursing care. A cooperative attitude presupposes mutual help and means sharing ideas and actions among peers, accepting their different points of view, which implies acceptance of diversity ${ }^{(20)}$. Cooperation is fundamental for the development of integrated actions, affects productivity, innovation and the quality of teaching/ learning and service ${ }^{(21)}$, and strengthens interrelationships, mutual help and teamwork.

In the professional field, empathy with the students because of their limitations or committed failures requires caution because the group has many expectations and fantasies in an atmosphere of uncertainty and a lot of anxiety. In interrelationships with one another outline a particularization movement from the voice intonation, its fluidity, interruptions in speech or even silence, especially considering that predictions about each another are not always true. The noise present in the communicative process corresponds to the internalized scenes in the inner world of each subject that are projected in the current relationships ${ }^{(2)}$. If someone feels excluded from any process, the basic anxieties are accentuated due to the unresolved contradiction ${ }^{(22)}$. Communication is a necessity in the context of nursing management and can be considered essential to mediate interpersonal relationships ${ }^{(23)}$ because it begins in itself, but is processed in another person's mind. In this articulation established in the professional field, if the communication between students, supervisors and nursing professionals gets confused, people can come to situations of progressive isolation and disintegration $^{(2)}$, constituting a split group.

From the dimensions of learning and the obstacles could presuppose the development of abilities to create alternatives, that dialectically contemplate the feel, the thinking and the articulated and operative acting ${ }^{(2)}$. The personal baggage that allows the technical property and experienced knowledge combined with the study and search for new knowledge contributes to alleviate the insecurities present in everyday life, forming the bond and interpretation of reality. Similarly, by welcoming students, the nursing staff shows the importance of integrated work, particularly in order that students understand the universe where they are inserted and can make suggestions to qualify this space. It is necessary to treat carefully the strict identity borders established by students and the team, whose learning is characterized as strong marks that they built.

This affirmation allows outlining the positive and negative tele paradox of students, supervisors and nursing professionals. When articulating themselves in the undergraduate practicum context, these individuals can break some stereotypes related to fears triggered by academic qualities and the transforming logic of teaching and learning such 
as approximation, recognition and overcoming barriers and critical problems they face and defend themselves from. By saying: I wish to work with somebody and I cannot; I do not want to work with others, means that someone makes the task difficult because of a process of recognition, reunion, a masking of reality with internal characters consisting of acceptance or rejection ${ }^{(2)}$.

The teaching fluidity in practice puts people involved in a relationship of reciprocity ${ }^{(5,16,24)}$ that requires a constant and compatible dialogue with the needs and possibilities ${ }^{(5)}$ of students, supervisors and nursing professionals, considering their roles in the construction of knowledge. Nevertheless, there are complex situations in action, such as the composition and dynamics of nursing work force, the quality and pertinence of care, and the development of hospital capacity ${ }^{(9)}$ expressed in the reality of services with all its tensions, contradictions and unpredictability resulting from the interaction between those involved with teaching ${ }^{(25)}$. Thus, in order that learning potentiates the managerial development of students, it is necessary to ensure they have teaching and professional support, thereby qualifying the interactivity and teamwork.

It is a consensus that when students feel embraced in face of adversity, although vulnerable, they can cope with the emerging demands. At this time, the contradictions and conflicts in the face of obstacles gain meaning and learning happens, a dialectical relationship with the students' internal and external world, and founded on their relationships of necessity and reality. On the other hand, in order that students act in the production of nursing care and stand out for their interference in the team, a conjectured look at dialectical principles governing interpersonal relationships can organize real conditions and the confrontation of contradictions in the practice field. Unlike conscious coping strategies, the defense mechanisms operate at an unconscious level, i.e., people do or say things without knowing why they did or said so, which reflects on different behaviors ${ }^{(26)}$, and makes explicit what they do not tolerate in the group. The due commitment and search for solutions regarding the dissatisfaction in interpersonal relationships, and the freedom and confidence in face of the undergraduate practicum without paralyzing fear and in spite of the obstacles, can generate the necessary motivation to overcome a problem and reach insights as a group ${ }^{(2)}$, which are qualitative leaps of learning that modify the process of thinking, feeling and acting.

If we also consider observing the emergence of the praxis by the notion of a person in connection with another ${ }^{(2)}$, such reflection leads to argue that it is necessary to prepare students, supervisors and nursing professionals to intertwine actions of care and commitment with each other for the effective teaching and learning ${ }^{(1)}$, when singularities of each individual, their cultural and historical stored background, and experiences create opportunities for new learning of hospital nursing management every day.

\section{CONCLUSION}

Students, supervisors, nurses and nursing technicians/ assistants are not only related people, but people produced in a praxis. Amid the work compass that drives decision-making with perspectives of teaching and learning nursing management in hospitals with vast explicit and implicit content, in these webs, the subjects use their individual CROS to act critically and with proposals on behalf of the group CROS.

By incorporating the concept of praxis in teaching and learning, there is echo in one of the understandings established throughout this study that it is precisely the notion of management learning happening jointly with the action of professionals in the practical context, although not in any action, but in those aimed at the task in the Pichon-Rivière sense of this term.

The immersion of students in the work routine favors learning and brings meanings to the organization and development of management in the production of nursing care in the intersection space with teaching. To this end, the dialogue spaces are necessary for nurses and nursing technicians/assistants feeling co-responsible for the formation of students, the same way it is expected that professors feel part of a team that follows academics. Thus, both will establish their social roles at the confluence of their knowledge, in their ways of acting and welcoming the other given the nuance linked to fluidity in teaching and learning of nursing management that demands a relationship of reciprocity and constant dialogue, compatible with the needs of students and the context, in an analogy of discovery of knowledge and existing.

The present study enables the visualization of knowledge expansion with implications for the teaching and learning of nursing management in care production, and it provides possibilities for further research in this area.

Regarding the study limitations, an aspect relates to the public teaching university hospital as the research field. It is characterized by a peculiar logistical and organizational contribution, and contingents of health and nursing professionals who favor the insertion and course of students in the undergraduate practicum. Other hospital care scenarios would possibly offer different dynamics and results, given the logistics supply and institutional organization. Furthermore, other places that also have undergraduate practicum programs in nursing management such as primary care health services deserve a specific analysis because of its peculiarities. This consideration refers specifically to teamwork, which, in these locations is planned to occur mainly through joint and integrated actions of the multidisciplinary team.

Objetivo: Analisar como se articulam alunos, professores e profissionais de enfermagem no ensinar e aprender administração em enfermagem na graduação, em um hospital universitário público. Método: A pesquisa insere-se na abordagem qualitativa, ancorada no referencial de Pichon-Rivière sobre grupo operativo. A coleta das informações deu-se entre outubro de 2013 e setembro de 2014 
e consistiu em Questionário Autoadministrado, Observação Participante e Grupo Focal. As informações foram submetidas à análise temática. Resultados: Do corpus da análise resultaram quatro categorias temáticas: o desconhecido e o inevitável; no ir e vir, atitudes, valores e novos vínculos; o diálogo e modos de agir no ensinar/aprender; a emergência da práxis. Conclusão: A articulação entre alunos, professores e profissionais de enfermagem dá-se em um ir e vir de atitudes, valores e novos vínculos em que o diálogo viabiliza os modos de agir no ensinar/aprender administração em enfermagem na graduação, possibilitando a emergência da práxis.

\section{DESCRITORES}

Pesquisa em Administração de Enfermagem; Educação em Enfermagem; Estudantes de Enfermagem; Grupos Focais.

\section{RESUMEN}

Objetivo: Analizar cómo se articulan los alumnos, profesores y profesionales de enfermería en la enseñanza y aprendizaje de la administración de enfermería en el pregrado, en un hospital universitario público. Método: La investigación se inserta en el abordaje cualitativo, anclado en el marco de referencia de Pichon-Rivière acerca del grupo operativo. La recolección de las informaciones ocurrió entre octubre de 2013 y septiembre de 2014, se constituyó en un Cuestionario Autoadministrado, Observación Participativa y Grupo Focal. Las informaciones fueron sometidas al análisis temático. Resultados: Del corpus del análisis resultaron cuatro categorías temáticas: lo desconocido y lo inevitable; el ir y venir, actitudes, valores y nuevos vínculos; el diálogo y los modos de actuar en la enseñanza/aprendizaje; la urgencia de la praxis. Conclusión: La articulación entre alumnos, profesores y profesionales de enfermería se da en un ir y venir de actitudes, valores y nuevos vínculos en que el diálogo hace viable los modos de actuar en la enseñanza/aprendizaje de la administración de enfermería en el pregrado, posibilitando la urgencia de la praxis.

\section{DESCRIPTORES}

Investigación en Administración de Enfermería; Educación en Enfermería; Estudiantes de Enfermería; Grupos Focales.

\section{REFERENCES}

1. Kaiser DE. Do implícito ao explícito: o ensinar/aprender administração em enfermagem no contexto hospitalar [tese doutorado]. Porto Alegre: Universidade Federal do Rio Grande do Sul, Escola de Enfermagem; 2015.

2. Pichon-Riviére E. O processo grupal. 10ª ed. São Paulo: Martins Fontes; 2016.

3. Waddah D, Kristina R. The visualisation of clinical leadership in the content of nursing education - a qualitative study of nursing students experiences. Nurse Educ Today. 2015;35(7):888-93.

4. Lyneham J, Levett-Jones T. Insights into Registered Nurses' professional values through the eyes of graduating students. Nurse Educ Pract. 2016;17:86-90.

5. Dall'Agnol CM, Magalhães AMM, Mano GCM, Olschowsky A, Silva FP. A noção de tarefa nos grupos focais. Rev Gaúcha Enferm [Internet]. 2012 [citado 2014 abr. 10];33(1):186-90. Disponível em: http://seer.ufrgs.br/RevistaGauchadeEnfermagem/article/view/13302

6. Pieczanski NL, Pieczanski A. Introduction to E. Pichon Rivière's 'The link and the theory of the three Ds (depositant, depositary and deposited): role and status' by E. Pichon Rivière. Int J Psychoanal. 2017;98(1):171-5.

7. Winters JRF, Prado ML. Processo de formação crítico-criativo: percepção dos formandos de Enfermagem. Rev Iberoam Educ Investig Enferm [Internet]. 2015 [citado 2016 fev. 10];5(2):17-24. Disponível em: http://www.enfermeria21.com/revistas/aladefe/articulo/160/

8. Lima MM, Reibnitz KS, Kloh D, Vendruscolo C, Corrêa AB. Diálogo: rede que entrelaça a relação pedagógica no ensino prático-reflexivo. Rev Bras Enferm [Internet]. 2016 [citado 2017 abr. 11];69(4):610-7. Disponível em: http://www.scielo.br/pdf/reben/v69n4/0034-7167reben-69-04-0654.pdf

9. Soares MI, Camelo SHH, Resck ZMR, Terra FS. Saberes gerenciais do enfermeiro no contexto hospitalar. Rev Bras Enferm [Internet]. 2016 [citado 2017 abr. 11];69(4):631-7. Disponível em: http://www.scielo.br/pdf/reben/v69n4/0034-7167-reben-69-04-0676.pdf

10. Meira MDD, Kurcgant P. Educação em enfermagem: avaliação da formação por egressos, empregadores e docentes. Rev Bras Enferm [Internet]. 2016 [citado 2017 abr. 11];69(1):10-5. Disponível em: http://www.scielo.br/pdf/reben/v69n1/0034-7167-reben-69-01-0016.pdf

11. Minayo MCS. O desafio do conhecimento: pesquisa qualitativa em saúde. 15a ed. São Paulo: Hucitec; 2016.

12. Kinalski DDF, Paula CC, Padoin SMM, Neves ET, Kleinubing RE, Cortes LF. Grupo focal na pesquisa qualitativa: relato de experiência. Rev Bras Enferm [Internet]. 2017 [citado 2017 abr. 11];70(2):424-9. Disponível em: http://www.scielo.br/pdf/reben/v70n2/pt_0034-7167reben-70-02-0424.pdf

13. Brasil. Ministério da Saúde; Conselho Nacional de Saúde. Resolução n. 466, de 12 de dezembro de 2012. Dispõe sobre diretrizes e normas regulamentadoras de pesquisas envolvendo seres humanos [Internet]. Brasília: CNS; 2012 [citado 2017 abr. 11]. Disponível em: http:// bvsms.saude.gov.br/bvs/saudelegis/cns/2013/res0466_12_12_2012.html

14. Pereira TTSO. Pichon-Rivière, a dialética e os grupos operativos: implicações para pesquisa e intervenção. Rev SPAGESP. 2013;14(1):21-9.

15. Llapa-Rodriguez EO, Carvalho TS, Gois CFL, Guimarães AMDN. Vivencias de los estudiantes de pregrado con las asignaturas de administración de enfermería. Invest Educ Enferm [Internet]. 2012 [citado 2015 Jan. 10];30(1):86-94. Disponible en: https://doaj.org/arti cle/9794eef132d24578b29e9304bdf505c9

16. Merighi MAB, Jesus MCP, Domingos SRF, Oliveira DM, Ito TN. Ensinar e aprender no campo clínico: perspectiva de docentes, enfermeiras e estudantes de enfermagem. Rev Bras Enferm [Internet]. 2014 [citado 2015 fev. 15];67(4):505-11. Disponível em: http://www.scielo.br/ pdf/reben/v67n4/0034-7167-reben-67-04-0505.pdf

17. Amado G. Os processos psíquicos no interior dos grupos de trabalho: para além de Bion e Pichon-Rivière. Cad Psicol Soc Trab [Internet]. 2014 [citado 2015 jan. 2];17(n.esp.1):97-110. Disponível em: http://dx.doi.org/10.11606/issn.1981-0490.v17i1espp97-110 
18. Lucchese R, Calixto BS, Vera I, Paula NI, Veronesi CL, Fernandes CNS. Group teaching in nursing/teaching group nursing practices guided by the Pichon-Rivière theoretical framework. Esc Anna Nery [Internet]. 2015 [cited 2015 Dec 17];19(2):212-9. Available from: http://www. scielo.br/pdf/ean/v19n2/en_1414-8145-ean-19-02-0212.pdf

19. Grando MK, Dall'Agnol CM. Desafios do processo grupal em reuniões de equipe da Estratégia Saúde da Família. Esc Anna Nery [Internet]. 2010 [citado 2014 ago. 17];14(3):504-10. Disponível em: http://www.scielo.br/pdf/ean/v14n3/v14n3a11.pdf

20. Cardoso ASF, Dall'Agnol CM. Group Process: reflections of a nursing team. Rev Esc Enferm USP [Internet]. 2011 [cited 2014 Dec 17];45(6):1406-12. Available from: http://www.scielo.br/pdf/reeusp/v45n6/en_v45n6a19.pdf

21. González-Chordá VM, Maciá-Soler ML. Evaluation of the quality of the teaching-learning process in undergraduate courses in Nursing. Rev Latino Am Enfermagem [Internet]. 2015 [cited 2016 Apr 09];23(4):700-7. Available from: http://www.scielo.br/pdf/rlae/v23n4/01041169-rlae-23-04-00700.pdf

22. Fabris F. A noção de tarefa, pré-tarefa e trabalho na teoria de E. Pichon-Rivière. Cad Psicol Soc Trab [Internet]. 2014 [citado 2014 dez. 17];17(n.esp.1):111-7. Disponível em: http://www.revistas.usp.br/cpst/article/viewFile/80639/84290

23. Oliveira KRE, Braga EM. The development of communication skills and the teacher's performance in the nursing student's perspective. Rev Esc Enferm USP [Internet]. 2016 [cited 2017 Apr 11];50(n.spe):32-8. Available from: http://www.scielo.br/pdf/reeusp/v50nspe/00806234-reeusp-50-esp-0032.pdf

24. Costa GD, Cotta RMM. "Learning-by-doing": social representations of healthcare students regarding reflective portfolio as a teaching, learning and assessment method. Interface (Botucatu) [Internet]. 2014 [cited 2016 Apr 09];18(51):771-84. Available from: http://www. scielo.br/pdf/icse/v18n51/en_1807-5762-icse-1807-576220140150.pdf

25. Messas JT, Leonello VM, Fernandes MFP, Gonçalves GCC, Bucchi SM, Mira VL. The educational environment of the undergraduate nursing course from the student perspective. Rev Esc Enferm USP [Internet]. 2015 [cited 2016 Apr 09];49(n.spe 2):106-14. Available from: http:// www.scielo.br/pdf/reeusp/v49nspe2/en_1980-220X-reeusp-49-spe2-0106.pdf

26. Acevedo MJ. Las defensas funcionales en la constitución del sujeto social. Subj Procesos Cogn [Internet]. 2013 [citado 2015 fev 17];17(1):17-41. Disponible en: http://www.scielo.org.ar/pdf/spc/v17n1/v17n1a01.pdf 